\title{
The return of the Jewish question and the double life of Israel
}

So now the Jew is mistrusted not for what he is, but for the anti-Semitism of which he is the cause. And no Jew is more the cause of anti-Semitism than the Jew who speaks of anti-Semitism. (Howard Jacobson, When Will the Jews be Forgiven for the Holocaust? $)^{1}$

Those who have always felt that Jews were powerful, controlling and out to destroy the world can now point in the direction of the Middle East and say: there you are. But for the conspiracy theorists, even the most appalling political and military machinations of Binyamin Netanyahu and the Israel Defence Forces - of Israel itself - are far less important than the creation of what David Aaronovitch, in Voodoo Histories, describes as a new kind of super-Jew: the Zionist. This is not, for the conspiracy theorist, the straightforward hate figure of the left. Rather, it is a character, or more importantly a group, to which all western governments are secretly in hock: unbelievably rich and powerful, and dedicated unswervingly to its own project, which is nothing less than the complete control of the world. Yes: Zionists are basically Spectre. (David Baddiel, 'Short of a Conspiracy Theory? You Can Always Blame the Jews'). ${ }^{2}$

The most significant expression of the reconfiguring of the Jewish question in the present period lies in the rise of negative representations of Israel and Zionism. While the stigmatisation of the idea of a Jewish nation may be traced back to the Enlightenment credo that everything should be granted to Jews 'as individuals' and nothing to Jews 'as a nation', it frames the Jewish question today in ways that could not have existed prior to the actual rise of Zionism as a political movement and especially prior to the formation of the state of Israel after the Holocaust.

It should go without saying that criticism of Israel is no less or more problematic than criticism of any other country. ${ }^{3}$ There is of course much to criticise, including occupation of Palestinian land, human rights abuses that flow from the occupation, anti-Arab racism in civil society, discriminatory state policies 
toward Israeli Palestinians, militaristic responses to external threats, etc. Nor does it exonerate the singularity of harms done by Israel to argue that the policies of neighbouring states are equally or in some cases far more subject to political criticism. The fact that other states do not live up to their responsibilities does not release Israel from its responsibilities for equal treatment of its citizens, for solidarity with strangers, for actively seeking an end to occupation, and for combating racism of all kinds. Criticism of Israel for its 'identitarian' constitutional status as a Jewish state is not invalidated by the fact that many of the states in the Middle East and North Africa analogously define themselves as 'Arab' or 'Islamic'. It is a predicament of all modern nation states to have to deal with contradictions that arise between the universal norms of constitutional government and the national boundaries in which these norms are set. Israel is no exception to this general rule.

It should also go without saying that 'criticism' of any country can be racist, antisemitic, Islamophobic or bigoted. We are familiar with the phenomenon of racial stereotypes parading as political criticism. When in response to injustices perpetrated by states or social movements we hear pseudo-anthropological statements concerning whole categories of people - for example, that, Africans cannot rule themselves, Arabs cannot comprehend democracy, Orientals do not value individuality, Americans are crassly materialistic, Europeans are marked by a postcolonial sense of their own superiority, etc. - it should be clear that criticism of any country can be imbued with prejudice. Witness the lengths to which citizens of postcolonial states go to distinguish democratic criticism of their own political regimes from negative stereotypes of 'peoples' that come from without. What is called 'criticism' of Israel is no exception. It may be based on the Jewishness of the people rather than on the democratic shortcomings of the state, or on some fusion of both. It may be premised on the harmfulness attributed to the idea of a 'Jewish nation' as such. Antisemitic criticism of Israel has parallels with racist criticism of other countries.

The problem we reference, that of viewing 'Israel' and 'Zionism' through the lens of the Jewish question, has much in common with the criminalisation of individuals. The criminalisation process has been explored within the discipline of sociology and the sub-discipline of the sociology of deviance. It involves both mechanisms of selection, interpretation, individuation and projection as well as incarceration, isolation, discipline and punishment. ${ }^{4}$ While the criminalisation of individuals on the one hand and that of states and peoples on the other are not identical processes, they share commonalities worth exploring. They include tendencies to essentialise the subject as fundamentally deviant; to single out only those actions of the subject that are indicative of wrongdoing; to interpret actions of the subject through an accusatory lens; to represent the subject only in relation to the question of guilt; to abstract the actions of the subject from their intersubjective and interactive contexts; to evaluate the subject in terms of deviation 
from abstract ideals no one can live up to; to project onto the subject the wrongs that exist in ourselves; and to bifurcate the world into two camps of criminality and honest society. Analogy between criminalising processes and the criminalisation of a whole people, nation or state is intended to help us think about what is involved in seeing Israel and Zionism through the lens of the Jewish question. We can illustrate the problem by exploring further the guilty verdicts passed on Israel and Zionism in some current 'critical' discourses.

Perhaps the most shocking of these is the charge of genocide, where Israel is accused of the very crime whose commission against Jews made the necessity for such a state so compelling. It forms part of the charge that Israel acts toward Palestinians 'like' Nazis acted toward Jews. ${ }^{5}$ As defined in the Genocide Convention of 1948, the crime of genocide specifies that it must involve intent to destroy a group in whole or in part through a series of actions of which mass killing is key but which also include causing serious bodily and mental harm, deliberately inflicting conditions of life calculated to bring about the physical destruction of the group, imposing measures intended to prevent births in the targeted group or forcibly transferring children of the targeted group to another group. There has been debate over such clauses. For example, after much legal argument, the International Tribunal on the Genocide in Rwanda came to the view that intent on the part of the perpetrator was a necessary component of a successful charge but could be deduced from foreseeable consequences and outcomes alone. ${ }^{6}$ To justify a charge of genocide in the case of the state of Israel, one would have to evidence the application of these criteria to Israel's treatment of Palestinians. It would have to be shown, for instance, that the Palestinian people have been destroyed as a group in part or whole and that the state of Israel has shown intent to commit genocide through measures designed to expel Palestinians, prevent Palestinian births, transfer Palestinian children to Israeli families, destroy Palestinian culture, etc. ${ }^{7}$ In relation to the conflict that took place during the Gaza war of 2014, in which over 2000 Palestinian soldiers and civilians were killed, as well as over 70 Israelis, it would have to be shown not only that physical destruction involving serious war crimes was committed by both sides but that the crimes committed by Israeli forces constituted genocide, which is by its nature a one-sided crime. Some insight may be gained by comparing charges of genocide directed against Israel in the course of the Gaza war with their relative absence when the Assad regime in Syria, only a few miles to the north, was responsible in the same period for killing well over 200,000 Syrians including some 2,400 Palestinians.

The charge of genocide does not bear close analytical scrutiny. It is not the result of informed political judgment of the kind upon which Hannah Arendt was so insistent, which requires us to think for ourselves, directly and carefully, about the application of concepts to particulars, to make meaningful comparisons, and to use appropriate standards of judgment to distinguish between 
crimes of a different order and magnitude. ${ }^{8}$ This failure indicates how what at first appears as a major sign of progress can be turned into its opposite.

Humanitarian law is a case in point. Today it has rightly become part of the formal structure of international law. It not only claims a 'soft' influence over states to take human rights into account but, in some instances, to demand compliance and declare a duty to obey. The norms of international law function as a higher law vis-à-vis that of states and there is an increasing number of treaty-based norms that obligate all states, whether or not they have signed the treaty in question. These include prohibition on genocide, as well as crimes against humanity, disappearances and torture. The dependence of international law on state consent has declined, as has the state's degree of freedom in interpreting and enforcing international law. International law is no longer involved only in conflicts between states but also in conflicts within states, affording international law a bigger role in responding to events such as civil wars, human rights abuses and humanitarian crimes.

One of the offshoots of the expanded scope of international law is the expanded use of categories of humanitarian law in political argument. Whether an act on the part of a state or state-supported actors is deemed to be in violation of international humanitarian law is now advanced as a basis for deciding on the legitimacy of the act in question and in some cases of the actor. Human rights have become the stuff of public debate, especially since the end of the Cold War, and their present public status contrasts with their relative invisibility in the post-1945 period, when international law was widely regarded as ineffective or narrowly technocratic in its concerns, and when citizens were inclined to rely on the resources of domestic legal systems or on their own moral and political judgments unmediated by law. The authority of humanitarian and human rights law has been invoked from a surprising number of intellectual and political perspectives, including critical-legal perspectives that do not normally uphold positive law as a privileged standard of legitimacy. It is difficult to imagine political argument any longer doing without this normative resource. Both the terminology of humanitarian law (not only genocide but also crimes of aggression, war crimes, crimes against humanity, torture, disproportionate response, collective punishment, etc.) and the terminology of human rights law (inhuman and degrading treatment, right to life, right to family life, right to free expression, etc.) play a vital role in public debate, as well as in legal judgment and this is as it should be. Were we to abandon this resource and revert back to a form of political argument in which notions of national interest on the one hand and moral claims of imperial powers on the other were the only prevailing points of reference, a vital ingredient of political argument that ties it to ethical life would certainly be lost.

The appeal to human rights in political argument, however, has a down side that disturbs this sense of progress. First, appeal may be made not to what 
humanitarian and human rights norms actually are but to some notion of what they ought to be or to the values they are supposed to embody, even when these values require the reform of actually existing international laws for their realisation. Second, the claim that an act of state accords with or violates humanitarian or human rights law is rarely tested in a judicial court, more often in the court of public opinion, and in political argument claims typically rely on the opinions of politicians and academics. The checks and balances that surround the expression of judicial opinion in legal cases are generally absent in political argument, so that the opinions expressed all too often utilise a selective interpretation of international law to support already pre-determined particular political convictions. Third, the appeal to one or other category of humanitarian or human rights law in political argument may be based not on the legal definition of the category in question, in this case on what is legally meant by 'genocide', but on common usage that may substantially differ from legal definitions. These categories are used in order to give rhetorical weight to an argument, whether or not there is an actual relation between what is claimed to be morally right and what is legally right according to the norms of international law. Fourth, humanitarian and human rights law form a complex array of norms, and different parties tend to pick and choose those aspects that favour their interests or convictions. One side may be well disposed to those elements of international law that outlaw terrorism but not those that relate to the mistreatment of prisoners of war. Another side may be better disposed to those elements of international law that uphold a right of resistance against occupation but less keen on international law's injunctions against harming civilians. Finally, both parties may be disdainful of existing norms of humanitarian law on the grounds that they are controlled by their opponents, but still use the rhetoric of humanitarianism and human rights to accuse the other of hypocrisy. ${ }^{\text {? }}$

These tendencies may be illustrated by debates in the Guardian newspaper in the UK over the legality as well as legitimacy of the Israeli invasion of Gaza in January 2009. One letter to the Guardian runs: 'As international lawyers, we remind the UK government that it has a duty under international law to exert its influence to stop violations of international humanitarian law in the current conflict between Israel and Hamas. A fundamental principle of international humanitarian law is that the parties to a conflict must distinguish between civilians and those who participate directly in hostilities' (14 January, 2009). This even-handed approach to the distinction between civilians and combatants was matched by numerous attempts to place international law on one side or the other of the conflict. The British Committee for the Universities of Palestine wrote in their Declaration of 'Gaza's Guernica': 'We say enough is enough. As long as the state of Israel continues to defy humanity and international law, we, the citizens of the world, commit ourselves to boycotting Israel' (28 December, 2008). On the other side, in response to the UNHCR Report on Gaza, one 
respondent argued that 'Hamas knowingly and deliberately targeted civilians and civilian targets in Israel and based itself in civilian areas' whilst there was no evidence that the phosphorous shells Israel used in civilian areas had been used 'in an illegal way' (7 May, 2009). When we look more closely at the appeal to humanitarian law in political argument, we find a propensity for all that is solid to melt into air.

Treating categories of humanitarian law, such as genocide, as trump cards that function to conclude argument saves us the work of having to make our own case. While such categories have rightly become a necessary part of political argument, they can all too easily substitute for political argument. To turn them into an absolute standard against which to measure the actions of states is to open a space for instrumentalising human rights, and paradoxically for undermining the basis of their own legitimacy. ${ }^{10}$ The application of concepts to particulars should be a matter of reflective judgment and not merely of instrumental utility.

A second charge has to do with the so-called 'apartheid analogy'. Here an analogy is drawn between Israel and the racist regime in South Africa, which at the tail end of the colonial era was rightly seen as a wholly illegitimate form of state. Certain aspects of what Israel has become, notably its occupation of Palestine and its colonial-like domination of Palestinians who live in Palestinian territory, have been converted into the central meaning of what Israel is. Contingent similarities between what Israel has become and the former apartheid state of South Africa have been translated into an essential identity. Certain contiguities between Israel and apartheid have thus shaded into what we call the 'apartheid analogy', and the chain of equivalence linking Israel and apartheid has come to form a standard trope in a diversity of left political circles. In classic antisemitism, 'the Jew' was treated as the symbolic representation of all that is rotten in the modern world. In contemporary antizionism we see a related phenomenon: Israel, Zionism and the Jewish state are treated as symbolic representations of all that is illegitimate in the present-day international community. Apartheid was the name of an overtly racist regime that deserved the opprobrium and isolation it received. In the metonymic use of apartheid, however, Israel is not called by its own name or understood in its own right but through the name of something seemingly associated with it. This rhetorical device has in turn been converted through processes of slippage into the metaphoric use of 'apartheid' in order to designate the core being of Israel. The attempt to portray an equivalence between Israel and apartheid has been pursued through a synecdoche in which the part - say the shooting of Palestinian demonstrators by Israeli soldiers or attacks on ordinary Palestinian civilians by Israeli settlers - is taken for the whole and then analogised with apartheid. In these ideologically charged slippages from contingency to essence, from metonymy to metaphor, from part to the whole, from contiguity to analogy, the missing term is that of comparison. 
To simply say that the 'Jewish state' is like apartheid, or is apartheid, is no substitute for analysis that studies similarities and differences between the one and the other. We might compare, for instance, gender inequalities in Saudi Arabia with racial inequalities under apartheid, or the constitution of the 'Jewish' state with that of 'Arab' or 'Islamic' states, or both with allegedly 'cosmopolitan' states in Europe. Analogy, however, saves us the work of comparison. We might also compare struggles against apartheid in South Africa - which found expression in documents like the Freedom Charter and were generally conducted in the name of achieving democracy - with struggles in Israel-Palestine, which have found expression in documents like the Hamas Covenant and Hezbollah Manifesto (which appear to provide no place for Jewish nationhood in 'Muslim' lands and scarcely more space for individual Jews). In place of comparison, a method of choice is to contrast the existing state of Israel to an abstract idea of what the state ought to be and then decree that it falls short. According to this rhetoric, the state ought to be cosmopolitan, universalistic, emptied of identitarian content, but the 'Jewish democratic state' of Israel violates this idea; or nationalism ought to be civic without any ethnic content but Zionism obstructs the realisation of this contemporary ideal. A more comparative method would compare how the 'Jewish democratic state' of Israel deals with the contradictory demands of state and nation with how other states deal with their own contradictory demands. The functional equivalence between such representations of Israel and apartheid lies in their power of delegitimation. Unable to create any genuine links, this rhetoric ends up with a form of catachresis that substitutes one term for the other. It means that Israel is not called by its own name but by the name of something else that was by common consent fit only for abolition. ${ }^{11}$

A third charge is that Israel is a major threat to world peace. This may be illustrated by a debate conducted in 2012 around a poem published by the celebrated German novelist Günter Grass, 'Was Gesagt Werden Muß ('What Must Be Said'). ${ }^{12}$ Christine Achinger recounts that most German critics did not claim the poem was antisemitic but criticised Grass for maintaining that Israel was threatening a nuclear attack on Iran that would 'extinguish the Iranian people', that Israel was a threat to world peace while President Ahmadinejad of Iran was merely a 'loud mouth', and that the threat of an Iranian nuclear bomb was a 'mere legend'. Grass was also criticised for claiming to break the silence imposed by the threat of being called antisemitic, while he had only recently broken his own silence about having been drafted by the Nazi regime as a member of the Waffen-SS. Achinger shows that German newspapers were generally critical of the Netanyahu government and warned against an Israeli attack on Iranian nuclear installations, but the main point for Grass' critics was that he presented Israelis as the new Nazis and Germans as cowed into silence by Israeli power. The characteristically ham-fisted reaction of the Netanyahu government, to bar Grass from entering Israel, lent superficial plausibility to Grass' self-presentation. 
A rush of readers' comments in German and British newspapers alleged that Grass was being hounded as a supposed 'antisemite' for no other reason than that he had dared criticise Israel. A translation of the poem published in the Guardian on 5 April 2012 reduced it to less than half its original length and omitted without any indication the most problematic passages. This made it harder for an English-language reader to see the German debate as anything other than a knee-jerk reaction to criticism of Israel. In a demagogic response, the Marxist writer Tariq Ali dispensed with any reference to the actual debate when he condemned the 'disgusting attacks on Gunter Grass'. According to Ali, Zionist self-assertion that the crime against the Jews of Europe was unique in the annals of history' combined with Zionist control over the media and American foreign policy to prevent ordinary people from recognising the crimes of Israel. The view that Grass' poem was labelled antisemitic in order to immunise Israel against criticism does no justice to a debate that had more to do with Europe's relation to its past than with Israel and Palestine. The expression of concern over antisemitism was treated as a sign of Zionist power and cunning rather than as the expression of a critical consciousness keen to avoid conspiracy theories in understanding modern society. ${ }^{13}$

The three charges against Israel and Zionism we have briefly discussed genocide, apartheid and threat to world peace - bear little analytical scrutiny, but the mark of the Jewish question is to elide suspicion with guilt. It represents Israel as the worst form of state, the Jewish nation as the worst sort of nationalism, and Jews who identify with Israel or refuse to condemn it as the worst accomplices. The rhetorical function of these charges is to say that there can be no greater crimes than those committed by Israel and its supporters; that Israel is the embodiment of criminality or evil, and that it must be punished through exclusion from the society of peoples. That the criminalisation of Israel also involves coercive measures we can illustrate here through two examples: the UK academic boycott campaign and the Charlie Hebdo affair in Paris.

The gravity of the charges made against Israel and Zionism have provided some of the emotional force behind the move to boycott Israeli academe, which has now become part of a larger campaign for Boycott, Disinvestment and Sanctions. In turn the boycott campaign has sustained the gravity of these charges in order to justify its own practices. As Pascal put it, if first you kneel, then you will believe. ${ }^{14}$ There is nothing new in the deployment of boycotts as a weapon of struggle. Consumer boycotts were deployed in apartheid South Africa by independent non-racial unions to put pressure on employers to meet workers' needs and trade union demands. At the other end of the legitimacy scale antisemitic boycotts were used by the National Socialists in Germany to exclude Jews from the social and economic life of the country. The academic boycott of which we now speak is aimed at singling out Israeli academic institutions, and only Israeli academic institutions, from the global academic community. 
The early history of this boycott campaign within academic unions in the UK goes back to the 1980s when some left groups labelled Israel 'the illegitimate state' and called for the 'no-platforming' of 'Zionist' organisations on university campuses. This campaign effectively singled out some Jewish Societies that had previously participated in the antiracist Anti-Nazi League. Some left-wing groups, who originally lent support to the campaign in a misplaced show of solidarity with the Palestinian struggle, backed off when confronted with basic antiracist arguments. ${ }^{15}$ When the boycott campaign resumed some fifteen years later, the climate had markedly deteriorated. In 2004 the Association of University Teachers (AUT) passed a motion which deplored the alleged 'witch-hunting' of colleagues who supported academic boycott of Israel, affirmed categorically that 'anti-Zionism is not anti-Semitism', and resolved to give support to members 'unjustly accused of anti-Semitism because of their political opposition to Israeli government policy'. In 2005 the AUT council resolved to boycott two Israeli universities, Haifa and Bar Ilan; when the vote was contested and a special meeting of the union convened, the boycott proposal was rejected. The successor union, University and College Union passed repeated resolutions calling for the boycott of Israeli academic institutions and repudiating any antisemitic connotation. In 2006 a resolution was passed denying that 'criticism of the Israeli government is in itself anti-Semitic' (our emphasis) and claiming that 'defenders of the Israeli government's actions have used a charge of anti-Semitism as a tactic in order to smother democratic debate and in the context of Higher Education to restrict academic freedom'. At the 2007 congress it was resolved that 'criticism of Israel cannot be construed as anti-Semitic' and at the 2008 congress that 'criticisms of Israel or Israeli policy are not, as such, anti-Semitic' (our emphasis). When complaints were made of the union's discrimination against opponents of the boycott campaign, of its invitation to pro-boycott speakers with proven antisemitic records, and of its indifference to concerns about antisemitism expressed by members, they were unanswered or rejected. In 2011 the union voted to dissociate itself from what was at the time a 'working definition of antisemitism' adopted by the European Union Monitoring Commission. Its most contentious clause focused on attempts to draw some kind of line between legitimate political criticism of Israel and antisemitic stigmatisation. The union maintained that the 'working definition' enabled opponents of the boycott to cry 'antisemitism' to stop people taking peaceful action against Israel, but had nothing to say about proponents of the boycott crying 'Israel' to stop people taking action against antisemitism. The cumulative effect of these initiatives was to remove antisemitism from the array of racisms the union would address if and when some kind of connection could be made with 'criticism of Israel'.

The key questions that challenged the academic boycott included the following: why is Israel being singled out for boycott when other countries are as or more repressive; why are Israeli civil society institutions sanctioned for crimes 
allegedly committed by the Israeli state; why is the exclusion of Israeli academic institutions from the global academic community not discriminatory on the basis of nationality or on the basis of religion if only Jewish members are targeted; why is the legal fiction endorsed that academic institutions can be boycotted without affecting the academic freedom of their members; why are normal procedures of solidarity with fellow trade unionists and academics not being followed in this case? And why are the key principles which the union supports - academic freedom, freedom of speech, exchange of ideas, rational argumentation, access to voices with which one might disagree, etc. - suspended? Proponents of the academic boycott have provided their own answers but the force of these questions has led them to make ever more wild and hypertrophic characterisations of Israel and Zionism. The academic boycott movement exemplifies the slippage from political criticism of a state to condemnation of a people. There is no reason to doubt the sincerity of those boycotters who present themselves as having no antisemitic intent, but this does not address their responsibilities regarding the effects of actions designed to unite conflicting political forces around the stigmatisation of Israel and the intent of others drawn into the campaign.

Some of the dangers we identify here were realised in the case of the murders that took place in Paris in early 2015 when, under the register of Je suis Charlie, a demonstration of an estimated million and a half people was held in Paris, and another million and a half people took to the streets elsewhere in France. They were among the largest public demonstrations in French history, held in protest against the murder of ten editors and cartoonists of Charlie Hebdo, a left-wing magazine, for having published cartoons representing the prophet Mohammed, one security officer and one (Muslim) police officer for having been in the way, and four shoppers in a Kosher supermarket for having been Jewish. The murders had an explicitly antisemitic dimension: the four Jews killed in the kosher supermarket were killed because they were Jews; the one woman on the editorial board of Charlie Hebdo who was murdered seems to have been murdered because she was Jewish. The murder of these Jews in Paris followed the murders of four people in the Jewish Museum in Brussels and before that of a parent and three schoolchildren (two of them his own) in a Jewish school in Toulouse. ${ }^{16}$ It was followed by the murder of a Jewish security guard outside a synagogue in Copenhagen. The murderers themselves were supporters of a jihadi Islamist movement, Al Qaeda in Yemen, which wore its antisemitism openly on its sleeve. The mass demonstrations against the killings expressed popular support for freedom of expression, religious tolerance, and opposition to religious fundamentalism. As one commentator put it, they represented resistance to 'the assassin's veto on critical discourse.' ${ }^{17}$

At the same time a discourse developed among left intellectuals that expressed scepticism toward the demonstrations that evolved in some instances into pejorative assessments of the public display of solidarity with the murdered people. ${ }^{18}$ 
Mehdi Hasan, writing 'as a Muslim', caught this mood when he maintained that Je suis Charlie was a symbol of the prejudices of the 'enlightened liberal West against backward barbaric Muslims'. He wrote that it was premised on double standards, since the journal refused cartoons mocking the Holocaust and had sacked one cartoonist (Maurice Sinet) in 2008 for antisemitic cartoons. Hasan maintained that Charlie Hebdo affirmed a right to offend Muslims without any corresponding notion of responsibility, assumed Muslims should have thicker skins, and used racist imagery to attack members of a powerless minority religion. He maintained that the solidarity demonstration was premised on the illusion of untrammelled freedom of speech and the hypocrisy of Western leaders supporting freedom of speech when, as he put it, Obama was demanding that Yemen jail an anti-drone journalist and Merkel was supporting laws against Holocaust denial. He also wrote that it 'sickened' him to see Benjamin Netanyahu, the right-wing Prime Minister of Israel, at the demonstration. ${ }^{19}$

There is a problem of double standards when national leaders link arms in defence of freedom of expression, which some violently suppress in their own countries. It is arguable whether a hypocritical show of commitment to freedom of expression is better than no show at all, but the existence of double standards within the elite underlines the significance of people defending this freedom consistently and protesting when it is violated. Those, for example, who oppose bans on the headscarf and burqa in French public institutions on freedom of religion grounds, would as a matter of sheer consistency be expected to defend Charlie Hebdo and oppose laws that criminalise blasphemy and apostasy. The cartoonist Bernard Holtrop commented on their newfound friends in the elite with characteristic Charlie Hebdo vigour: 'we vomit on all these people'. The hypocrisy of elites does not make freedom of speech itself any less valuable. The journal's attacks on the idea of 'blasphemy' represented acts of solidarity with secularists in countries that criminalise blasphemy, and are a reminder that the first victims of jihadism are usually Muslims. They are an expression of solidarity with journalists assassinated by Islamic fundamentalist forces (like the Syrian Raed Fares by ISIS) or brutally punished by the Saudi Arabian government (like the blogger Raif Badawi).

The danger of Islamophobic appropriation of the protest by movements like the French Front National, and other nationalist forces opposed to the 'Islamicisation of Europe', should not allow us to forget that the assembly of people who gathered in Place de la République overwhelmingly expressed inclusive and democratic rather than Islamophobic sentiments, or that the organisers of the demonstration explicitly excluded the Front National. The representation of Charlie Hebdo as Islamophobic has been deployed as grounds for withdrawing solidarity from the victims of the violence. There is, however, an obvious difference between defending someone's right to say something, including something controversial and shocking, and endorsing the content of what is said. The 
critique of the content of the cartoons as Islamophobic is in any event highly tendentious. The ambiguities of Luiz's cartoon of the prophet Muhammad shedding a tear under the words Tout est pardonné and carrying a placard saying Je suis Charlie are part of its strength, but the cartoon suggests that Muhammad, whose name was invoked by nihilistic men of violence, is innocent of the crimes they committed. An earlier cartoon has Muhammad in tears saying: c'est dur d'etre aimé par des cons ('it's hard being loved by shits'); another has Muhammad beheaded by a black masked fanatic under the words 'If Muhammad returned'; and a third has a cartoonist in gay embrace with a bearded Mullah under the words L'amour plus fort que la haine ('Love stronger than hate'), which became one of the slogans of the demonstrations. The point is not to defend everything Charlie Hebdo did, but its attacks on 'religious' targets of different denominations go back to a Rabelaisian and then revolutionary anti-clerical tradition. There was a cartoon of Catholic priests declaring that 'every sperm is sacred' and another of an Israeli Jewish settler killing a Palestinian farmer and saying 'Take that, Goliath'. Charlie Hebdo was a creature of the post-68 New Left, remained on the left and had close ties with SOS Racisme. The editor Charb was in the Front de Gauche, campaigned against neoliberal changes to the European constitution, and illustrated Marx: A User's Guide. Bernard Maris, a co-editor, was a member of an anti-globalisation movement called Attac and campaigned against austerity, corporate corruption, tax havens and the arms industry. Being on the left does not mean that one is not Islamophobic but the damaging attacks that have been launched on the journal bring to mind similar attacks on the work of Salman Rushdie after a Fatwa was declared against him in $1989 .{ }^{20}$

In this Alice in Wonderland world, everything is upside down. Reaction in the form of jihadi dreams of a Caliphate, conspiracy thinking about Jews undermining Islam, and attacks on Muslims who disagree, is treated as counter-hegemonic, while antiracism and anti-homophobia in the form of Charlie Hebdo are treated as reaction. The most important distinctions are not made: like that between speech designed to incite violence and hatred which is not and should not be protected in law, and speech that is anti-religious and may appear blasphemous from the point of view of the pious, which is and should be protected. ${ }^{21}$ The prosecution of the comedian Dieudonné M'bala M'bala for inciting hatred of Jews (after he declared inter alia 'Je suis Charlie Coulibaly', the name of the killer of Jews in the supermarket), may be likened to that of the actor Brigitte Bardot and journalist Eric Zemmour for inciting hatred of Muslims; they were all designed to protect people from violence. Laws against blasphemy by contrast protect the state and state-endorsed religions from the people.

As far as the antisemitic dimensions of the violence were concerned, one response has been to neglect it altogether or draw some kind of equivalence between the killing of French Jews in Paris and the killing of Palestinians in Israel. In a competition of victimhood in which concern for one supplants 
concern for the other, the notion is born that injustices committed by 'Jews' could go some way toward explaining the rage that led to 'their' murder. ${ }^{22}$ Rather than see Islamophobia and antisemitism as connected forms of racism, the temptation is to set up what Kenan Malik calls an 'auction of victimhood' in which 'every group attempts to outbid all others as the one feeling most offended'. ${ }^{23}$ Let us not lose sight of the connection between the attack on Charlie Hebdo and that on Jews - that the attack was simultaneously directed at the right to freedom of expression and at the lives of Jews. Even if the grocery shoppers were innocent, it has been said, it is a reminder that Jews a thousand miles away are guilty of terrible crimes against Islam. ${ }^{24}$ But let us not confound the pretext given for crimes and our understanding of them. In Toulouse the pretext given by Mohammed Mera for killing Jews was that 'the Jews kill our brothers and sisters in Palestine'. In the Charlie Hebdo affair, the pretext given by the Kouachi brothers was to 'avenge the Prophet Muhammad'. In the random killing of 130 people on 13 November 2015 in Paris, the pretext given by the Islamic State of Iraq and the Levant (ISIL), which claimed responsibility for the attacks, was that they were in retaliation for French airstrikes on ISIL targets in Syria and Iraq. ${ }^{25}$ Pretexts are significant but it would be erroneous to treat the killers as spokespeople of the wider Muslim community or conclude that if only the Israelis had not killed Muslims in Palestine, if only Charlie Hebdo had not caused offence with its cartoons, if only the French air force had not bombed targets in Syria and Iraq, then the raison d'être of the attacks would no longer exist.

\section{The return of the Jewish question}

Contempt for rights, lack of solidarity with victims, neglect of antisemitism, belief in the harmfulness of Jews - the markers of the old Jewish question are not absent in the new. The practical problem is how to transcend this whole perspective. At issue is our capacity to smell the scent and hear the echoes of an old prejudice even when it assumes the forms of enlightenment, progressiveness, antiracism and cosmopolitanism. The point is not to abandon these principles but to stay with their substance. Sometimes we have to rely on our own judgment even if it is at odds with the opinion of many good people around us. If the markers of our cosmopolitan existence are indeed a common sense in which we learn to share a common world with others, and an enlarged mentality in which we learn to see the world from the standpoint of others, ${ }^{26}$ these are the very capacities the Jewish question excises when it demands that consciousness of sharing a common world with Israel, and seeing the world from its standpoints, should in principle be renounced.

The return of the Jewish question involves a distortion of universalism that sees Jews as the problem and demands a solution to this problem. Today this demand focuses on the exclusion of the Jewish nation from world society. 
Condemning a people is no substitute for political thought, even if it presents itself as resistance to power, speaks the language of universalism and prides itself on its left credentials. ${ }^{27}$ The practical question for the left is how to escape the prison house of the Jewish question.

The Jewish question is not just an attitude of hostility to Jews or to those who invoke the sign of 'the Jews' but a theory designed to explain the winners and losers of capitalist society. It is formulated in terms of dichotomies - the modern and the backward, the people and its enemies, the civic and the ethnic, the postnational and the national, imperialism and anti-imperialism, power and resistance, the West and the rest. In every case Jews appear as the 'other of the universal': a backward people who stubbornly resist progress or an all-too-clever people who manipulate progress and hold the world in its thrall; a nation within a nation that is endemically treacherous or a nation unlike all other nations in that it is not a valid nation at all; a 'settler-colonial' state in an otherwise decolonised world or a 'cosmopolitan elite' with no comprehension of global responsibility. ${ }^{28}$ The 'othering' of Jews inevitably creates an inequitable economy of compassion and a restrictive arena of solidarity. ${ }^{29}$ In its spiritless radicalism it at once turns Israel into the primary source of violence in the world and places Palestinians into a single identity script as victims, only as victims and only as victims of Israel. Just as it subsumes the plurality of Jewish voices to 'the Jews' and the plurality of Israeli voices to 'Israel', it also subsumes the plurality of Palestinian voices to 'the Palestinians' and risks turning them into ciphers of our own resentments. It erases uncertainty and complexity in favour of a bifurcated economy of identity and non-identity. It makes us blind to the universal insight that no human being is entirely different from another even where unequal social structures and cultural peculiarities make this hard to see. ${ }^{30}$ Israel is represented not as a complex society with real people embroiled in internal and external conflicts, but as a vessel into which 'we' who cannot shake off the illusion of our own universality - be it we Europeans, we on the left, we cosmopolitans, or we diasporic Jews - project what is most troubling in ourselves and so preserve the good for ourselves. Jews never were the problem; they are not the problem now. What has to be dealt with is not a Jewish question, but the question of antisemitism that generated the Jewish question in the first place.

A first step toward emancipating the left from the shadow of the Jewish question is to recognise what it is: not only in its emphatically antisemitic form as 'the final solution' but also in its less lethal forms within Enlightenment, within emancipation struggles, within revolutionary Marxism, within critical theories, within solidarity movements, and within the contemporary left. While classic antisemitism constitutes the bottom line of the Jewish question, in all its forms it is premised on projections concerning the harmfulness of Jews that has a deep affinity to antisemitism. Today there are not many who raise the spectre of the Jewish question as an explicit question to be set and solved, but if it has mainly 
gone underground it does not mean that it no longer exists. It still provides the grammar, vocabulary, theoretical premises - in short, the conceptual ground - on which antisemitism can continue to grow. The Jewish question is a discourse of prejudice toward Jews, but it is also a discourse of ignorance and obfuscation that distorts our understanding of the world and our conception of humanity. The posing of this question inflicts harm on all who pose it. When the left succumbs, we should not be surprised if the result is not only to disable it from providing solidarity to Jews even when they are most under attack, but also to fail at a general level to recognise that all human beings are members of a common humanity and that our human status matters whatever particular category we belong to. The good news is that in the struggle to supersede the Jewish question we do not start from scratch. In fact, we have the best traditions of critical thought to inspire and guide us.

\section{Notes}

1 Howard Jacobson, When Will the Jews be Forgiven for the Holocaust?

2 David Baddiel, 'Short of a Conspiracy Theory? You Can Always Blame the Jews', Guardian, 22 July 2015.

3 It is difficult to say anything about Israel itself that does not provoke ideologically driven responses. Suffice to say that in Israel we find a state that was brought into being in reaction to the near-destruction of those designated Jews, authorised by the international community through the United Nations, confronted by the hostility of other newly independent states which defined themselves as 'Arab' and which denied the legitimacy of a 'Jewish' state. Its population was swollen by surviving European Jews who could find no place in the West and by 'Arab Jews' expelled or excluded from newly independent states in the Middle East and Maghreb. Neighbouring Arab states did not accept the UN division of the British mandate of Palestine into two states and sought to conquer and divide the territory between themselves. In the course of wars with these states, Israel was implicated in driving out or not allowing back in a substantial part of the Arab population of Palestine and in discriminatory practices against the substantial Palestinian minority that remained in Israel. A complex and an original array of elements came together in the formation of Israel, which only look like the unfolding of the original idea of Zionism in retrospect. The unacceptable occupation of Palestine since 1967 has been one result of these unending hostilities. No understanding of Israel can flow from already possessed truths, or from a conception of 'Zionism' as an evolving essence, or from imposed silences. Our understanding is bound to be distorted if we proceed as if the Holocaust never happened, as if Jews were not forced out of 'Arab' lands, as if Israel were never attacked, as if Jewish national movements do not have commonalities with other national movements, as if there is no plurality in Israeli society, and as if violence does not have intersubjective origins.

4 For our own elaboration of the criminalisation thesis, see Robert Fine, 'Labelling Theory: An Investigation into the Sociological Critique of Deviance', Economy and 
Society, 6 (2), 1977: 166-193; 'Bourgeois Power: Sartre and the Modern Prison', Economy and Society, 6 (4), 1977: 408-435; and 'Struggles against Discipline: The Theory and Politics of Michel Foucault' in Barry Smart (ed.), Michel Foucault: Critical Assessments (London: Routledge, 1994).

5 There are more or less sophisticated versions of this charge. For examples of the cruder kind, see those cited in Spencer and Valentina di Palma, 'Antisemitism and the Politics of Holocaust Memorial day in the UK and Italy', 71-83. More sophisticated charges have been mounted by, for example, Martin Shaw in 'The Question of Genocide in Palestine in 1948', and rebutted by Omer Bartov in 'The Question of Genocide in Palestine in 1948: A Reply to Martin Shaw', both in Journal of Genocide Research, 12 (3 and 4), 243-259.

6 Issues concerning the definition of genocide are discussed in Philip Spencer, Genocide since 1945 (London: Routledge, 2012), 13-14.

7 The 'genocide' thesis in relation to Israel is discussed in Philip Spencer, 'The Left, Radical Antisemitism, and the Problem of Genocide', Journal for the Study of Antisemitism, 2 (2010), 501-519.

8 In this context, it is striking how those who claim to follow Hannah Arendt in attacking Israel seem to have entirely ignored her own writings on what is in involved in political judgment.

9 A case in point is the contention that international criminal courts are selective in whom they choose to prosecute for war crimes, a selectivity based not on the nature of the crimes that have been committed or on the harm they have caused but on who the accused are and whether they are deemed allies or enemies of those who authorise the court. This argument has been raised to question the legitimacy of existing international criminal courts and tribunals (David Chandler, 'International Justice' in Daniele Archibugi (ed.), Debating Cosmopolitics (London: Verso, 2003), 27-39). However, the fact that some offenders are not prosecuted does not invalidate the prosecution of others in this sphere of law, any more than the fact that some speeding offences are not prosecuted does not invalidate the prosecution of others.

10 Our observations concerning the expanded scope of international humanitarian law in political argument are drawn from Robert Fine, 'Thoughts on the Legitimacy of Human Rights' in Aldo Mascareno and Kathya Araujo (eds.), Legitimization in World Society (Farnham: Ashgate 2012), 25-44.

11 The same kind of problem is present in the idea that Israel is a 'settler-colonial' state. This label requires serious analysis but comes from applying a pre-existing model of states colonised by European powers to a situation with its own distinctive characteristics. Many of the 'colonisers' did not come from 'the West' but from Eastern Europe and Arab lands; they were normally fleeing persecution which became genocidal in Europe; they perceived an attachment to this particular area that was born in part out of the fact that Jews had lived there for millennia; and they entered a world of competing national movements (Zionist, Arab nationalist, Palestinian, Islamist, etc.) which developed in the same post-imperial space. The danger present in the use of this negative epithet is that rather than stimulate thought and judgment, it substitutes for them. 
12 We are indebted to the research of the German scholar Christine Achinger for this analysis. See Christine Achinger and Robert Fine, 'Introduction' in Christine Achinger and Robert Fine (eds.), Antisemitism, Racism and Islamophobia: Distorted Faces of Modernity (London: Routledge, 2015), 1-13.

13 Tariq Ali, 'The Disgusting Attacks on Gunter Grass', Counterpunch, 10 April 2012, www.counterpunch.org/2012/04/10/the-disgusting-attacks-on-gunter-grass/ (accessed 10 September 2014).

14 Slavoj Žižek analyses the dialectic of kneeling and believing thus: 'Pascal's "Kneel down and you will believe!" has to be understood as involving a kind of self-referential causality: "Kneel down and you will believe that you knelt down because you believed!" The second thing is that, in the "normal" cynical functioning of ideology, belief is displaced onto another, onto a "subject supposed to believe," so that the true logic is: "Kneel down and you will thereby MAKE SOMEONE ELSE BELIEVE!" ... To believe "directly," without the externalizing mediation of a ritual - is a heavy, oppressing, traumatic burden, which, through exerting a ritual, one has a chance of transferring onto an Other ... Let us take the affirmation "I believe." Its negation is: "I do not really believe, I just fake to believe." However, its properly Hegelian negation of negation is not the return to direct belief, but the self-relating fake: "I fake to fake to believe," which means: "I really believe without being aware of it." Is, then, irony not the ultimate form of the critique of ideology today - irony in the precise Mozartean sense of taking the statements more seriously than the subjects who utter them themselves?' Žižek, 'What's Wrong with Fundamentalism?', www.lacan.com/zizpassion.htm (accessed 30 November 2015).

15 For a thorough study of this successful antiracist campaign, see Dave Rich, Zionists and Anti-Zionists: Political Protest and Student Activism in Britain, 1968-1986, PhD thesis (Birkbeck College, University of London, 2015).

16 On the escalation of antisemitic violence in France in recent years, see the five part series in Tablet by Marc Weitzmann, www.tabletmag.com/tag/frances-toxic-hate and also Marie Brenner, 'France's Scarlet Letter', www.vanityfair.com/news/2003/06/ france-muslim-jewish-population (both accessed 20 October 2015).

17 Timothy Garton Ash, 'Defying the Assassin's Veto', New York Review of Books, 19 February 2015, www.nybooks.com/articles/2015/02/19/defying-assassins-veto/.

18 Richard Seymour in the Jacobin described the demonstration as 'platitudinous, mawkish and narcissistic' - a 'blackmail that forces us into solidarity with a racist institution'. It became something of a vogue to say 'Je ne suis pas Charlie'. Jon Wilson in Labour List referred to what he called the 'obvious racism' of Charlie Hebdo. Jacob Garfield in the Hooded Utilitarian described Charlie Hebdo as 'xenophobic, racist, sexist, homophobic, and anti-Islamic' and claimed its editorial board was all-white, as if this were itself a damning argument. It was actually quite untrue - one of the murdered journalists was the Algerian, Moustapha Ourrad.

19 Mehdi Hasan 'As a Muslim, I'm Fed Up With the Hypocrisy of the Free Speech Fundamentalists', New Statesman, 13 January, 2015, www.newstatesman.com/ mehdi-hasan/2015/01/muslim-i-m-fed-hypocrisy-free-speech-fundamentalists (accessed 10 May 2015). 
20 For a probing analysis of the Satanic Verses controversy see Kenan Malik, From Fatwa to Jihad: The Rushdie Affair and its Legacy (London: Atlantic Books, 2009).

21 In 1979 the Monty Python film Life of Brian was treated as blasphemous by various religious groups and local authorities in the UK and the US. It was condemned as such by Malcolm Muggeridge and Mervyn Stockwood, the Bishop of Southwark, in a BBC televised debate.

22 See Paul Berman's compelling reflections on this aspect of the Charlie Hebdo affair in Tablet (14 January 2015 and 26 May 2015) 'The Charlie Cover', www.tabletmag.com/ jewish-arts-and-culture/books/188320/the-charlie-cover; and 'Cruelty \& Perversity: Postprandial Reflections on the PEN Protesters. The Grim Satire of the "Charlie Hebdo" Controversy, in Context', www.tabletmag.com/jewish-arts-and-culture/ books/191181/reflections-on-pen-protesters (both accessed 12 June 2015). One issue concerns the economy of compassion that responds with justified compassion to the sufferings of Palestinians only to convert compassion for the victim into hatred of the victimiser or those it holds guilty of causing the suffering of Palestinians. It neglects other sources of victimisation of Palestinians and the interests ordinary Palestinians have in opposing antisemitism, not least when it is deployed by their own political leaders as a means of internal repression.

23 Kenan Malik writes: 'The impact of censorship is in fact to undermine progressive movements within minority communities. Take the controversy over the Danish cartoons. There's a general assumption that all Muslims were offended by the cartoons and that all Muslims wished to ban them. Not true ... The multiculturalist censor demands respect not just for the person but also for his or her beliefs. And in so doing they undermine individual autonomy, both by constraining the right of people to criticise others' beliefs and by insisting that individuals who hold those beliefs are too weak or vulnerable to stand up to criticism, satire or abuse'. Intelligence Debate, Royal Geographical Society, London 7 June 2006, www.kenanmalik.com/debates/ free_speech_IQ2.html (accessed 30 November 2015).

24 Some Iranian and Arab media claimed that Israel, through its secret service, Mossad, orchestrated the attacks and planned the attacks in order to punish France for recognising Palestine as a state or to discredit Muslims. See Marc Weitzmann, 'The Failure of Intelligent Explanations: France Grapples with the Aftermath of Attacks that are no Longer "Just Against Jews", Tablet, 25 November 2015, www.tabletmag .com/jewish-news-and-politics/195371/france-intelligent-explanations (accessed 20 October 2016).

25 The attack on the Bataclan music venue may not have been chosen at random. It had already figured for some time as a potential target of antizionist violence perhaps because it had, until recently before the massacres, Jewish owners, www.lepoint.fr/ societe/le-bataclan-une-cible-regulierement-visee-14-11-2015-1981544_23.php (accessed 25 July 2016).

26 Hannah Arendt drew the concepts of 'common sense' and 'enlarged mentality' from her reading of Kant's Critique of Judgment. See Hannah Arendt, Lectures on Kant's Political Philosophy (Chicago: University of Chicago Press, 1982).

27 For powerful critical analyses of contemporary left antisemitism from the left, see David Hirsh 'The Corbyn Left: Politics of Position and Politics of Reason', Fathom, 
Autumn 2015, http://fathomjournal.org/the-corbyn-left-the-politics-of-positionand-the-politics-of-reason/ (accessed 30 November 2015); Alan Johnson, 'The Left and the Jews: Time for a Rethink', Fathom, Autumn 2015, http://fathomjournal.org/ the-left-and-the-jews-time-for-a-rethink/ (accessed 30 November 2015); Michael Walzer, 'Islamism and the Left', Dissent, Winter 2015 www.dissentmagazine.org/ article/islamism-and-the-left (accessed 30 November 2015).

28 Some see Israel as the instrument of Western neo-imperialism in the Middle East and some go further in viewing Israel as controlling policy-making in the US and Britain. This reversion was first presented to an academic audience in John Mearsheimer and Stephen M. Walt, The Israel lobby and U.S. Foreign Policy (New York: Farrar, Straus and Giroux, 2007).

29 We may point to failures within much of the European left to show solidarity with the Iraqi opposition under Saddam or with the Iranian 'Green Revolution' of 2009-2010, and conversely the enthusiasm within some sections of the European left for Hezbollah, Hamas and jihadi movements opposed to the West. Dualist thinking today mirrors uncritical support in the past for the regimes of Nasser in Egypt or the Ba'ath in Syria in spite of the fact that these regimes oppressed and killed their own domestic left-wing oppositions. For a moving analysis of neglected human rights struggles against Islamic fundamentalism, see Karima Bennoune, Your Fatwa Does Not Apply Here: Untold Stories from the Fight Against Muslim Fundamentalism (New York: W.W. Norton and Co, 2013).

30 For an insightful discussion of reflexivity and positionality see Glynis Cousin, 'Positioning Positionality: The Reflexive Turn' in Maggie Savin-Baden and Claire Howell Major (eds.), New Approaches to Qualitative Research: Wisdom and Uncertainty (London: Routledge Education, 2010), 9-18. 